\title{
NATION BuILDing, ENGLISH AS AN \\ INTERNATIONAL LANGUAGE, MEDIUM OF \\ Instruction, and Language Debate: Malaysia ANd Possible Ways ForWARd
}

\author{
Phan Le Ha ${ }^{\mathrm{a}}$ \\ Joyce Kho \\ Brendan Chng \\ Monash University
}

\begin{abstract}
In this article, we discuss Malaysia's major language policies surrounding Bahasa Malaysia and English as medium of instruction (MOI) since its independence. We show how issues involving a national language vis a vis English are shaped by different ethnic and social groups' competing views regarding these languages. We argue that the language debate in Malaysia is largely an emotive one that carries a historical baggage which no one is yet ready to discard and until such time, it will continue to represent a nation divided by nationalism, race-based politics and globalisation. However, we also interpret the Malaysian government's termination of English as the MOI in certain key school subjects starting in 2012 as not necessarily an arbitrary rejection of English but as a positive move, given the many problems associated with the over-reliance on English in education and language policies throughout Asia. We, thus, see the most recent act known as 'To Uphold Bahasa Malaysia \& To Strengthen the English Language' (MBMMBI) as a necessary, firm, strategic and timely response by the Malaysian government to globalisation, nation building, the increasing international role of English, and the pressure to produce knowledge and maintain national cultural identity in today's world
\end{abstract}

KEYWORDS: language debate, English as an International Language, Malaysia, nation building

\section{Introduction}

With the growing emphasis on English in Asia, English as a commercial, political, intellectual, and cultural resource is increasingly appropriated by countries and schools and universities in the Asian region. Systems of education in Asia have accordingly promoted the development of Englishmedium programs and partnerships with overseas entities, almost invariably through English. Such programs and products are widely assumed to be more authoritative and more advantageous in the global labour market (Singh and Han, 2008).

While English is assumed to be fundamental in educational (reform) strategies, it is not regarded in the same way in all national settings. For example, while it has become abundantly clear that the policies and practices of education are not neutral (Tsui and Toleffson, 2007; Rizvi and Lingard, 2010; Singh, 2010), what is not clear is how specific colonial histories, local politics and cultural traditions shape the role of English and how this is interpreted, projected, promoted and justified in particular national educational settings. As such, to what extent are we really witnessing globally converging notions concerning the educational significance of English? How is this emphasis on English resisted or utilized for individual, institutional and national benefits?

We, in this article, first show how and in what ways the role of global English is interpreted and justified in different countries in Asia, while briefly examining in what ways issues involving a national language vis a vis English in many communities and nation states are far more complex when different ethnic and social groups hold competing views regarding the national language and what meaning each gives to such language. At the same time, utilitarian perspectives and the formation

correspondence can be directed to: ha.phan@monash.edu 
of a global elite community closely linked to the widespread use of English has pressured nation states to seriously engage with this assumed most powerful language of our times, as will be seen in the case of Malaysia presented in the subsequent sections. In particular, Malaysia's major language policies surrounding Bahasa Malaysia and English as the medium of instruction (MOI) in schools and universities since its independence are specifically drawn on. We then focus on Malaysia's two major policies regarding $\mathrm{MOI}$ : the sudden change from Bahasa Malaysia as the MOI to English for Mathematics and Science in 2003, which was reversed in 2012 following a decade of failure seen from various angles; and the introduction of a new language policy after the reverse, known as ' $T o$ Uphold Bahasa Malaysia \& To Strengthen the English Language' (MBMMBI).

We seek to understand how the main ethnic groups in Malaysia, particularly the Malays and the Chinese, have resisted and/or utilised varied emphases on English and Bahasa Malaysia at the individual, community and national levels as well as to claim and exert different kinds of power. We argue that the language debate in Malaysia is largely an emotive one that carries historical baggage which no one is yet ready to discard and until such time, it will continue to represent a nation divided by nationalism, race-based politics and globalisation.

However, we also argue that the Malaysian government's most recent decision to terminate English as the $\mathrm{MOI}$ in certain key school subjects is a positive move, given the many well-discussed problems associated with the over-reliance on English in education and language policies throughout Asia, for example in Japan and in Indonesia (Sugiharto, 2008; Huang, 2009; Sakhiyya, 2011; Phan Le Ha, 2013; Supriyanto, 2013). This act ought to be recognised as a good move, given Malaysia's constant dilemma of how to choose between preserving the evolving national identity and pursuing national interests through the English language to actively participate in the international community. This is also a good move in terms of enabling advanced scholarship building in Bahasa Malaysia, alongside the English language.

\section{The Three Circles of English, Their Altering Borders, and Language and Identity in Asia}

Studies in relation to the international role of English often cite Kachru's $(1985,1986)$ premier work, in which he coined and discussed the three circle model of English, the Inner Circle, the Outer Circle and the Expanding Circle. In this model, the Inner Circle constitutes the traditional bases of English, largely referring to native-English-speaking countries (e.g. Australia, Canada, the USA and the UK). The Outer Circle includes countries where English is used as a second and/or official national language. Many of these countries were former colonies, either of Britain (e.g. Malaysia, Singapore, India) or the US (e.g. the Philippines). Finally, the Expanding Circle contains countries that use English as a foreign language (e.g. Vietnam, China, Japan).

Nevertheless, together with the increasing dominance of English and new developments in English language studies particularly in the areas of World Englishes, English as an International Language, English as a Global Language and English as a Lingua Franca (for example, Crystal, 2003; Jenkins, 2009; Kirkpatrick, 2012), this model has been revisited over the past decades. In addition, the growing importance of new economic and knowledge powers such as India, China and Brazil accompanied by the need to promote themselves more effectively through the medium of English has made the borders of these circles even more blurred. As further debated by Rajadurai (2005, p.114), "however, I feel that as revolutionary and valuable as the [Kachruvian] model has been, the pace with which English has spread, the power and politics associated with it, and the sweeping consequences of globalization have made a review of the Kachruvian circles timely".

By the same token, the borders between these circles are being altered by changing language education policies in different national contexts. Specifically, for instance, Malaysia has oscillated between the Outer and Expanding Circles since its independence. In Malaysia, the status of and attitudes towards English are ambivalent, due to the influence of nationalism, the dominance of Bahasa Malaysia (especially in non-urban communities), competing pressures from neighbouring 
countries, especially Singapore, and religious agendas concerning Islam (Altbach and Knight, 2007; Hamid and Moni, 2011; Welch, 2011). Singapore, meanwhile, has been quite consistent since the 1960s with its English language policy, placing English at the heart of its educational and administrative system alongside other official languages (Chew, 2007). However, debates surrounding what it means to be Singaporean and what consists of Singaporean national cultural identity have also questioned the dominant role of 'imported' English on this island. As such, Singlish, a colloquial variety of English used in Singapore, seen as a cultural identity marker for Singaporeans has been fought against quite harshly by the government and a number of scholars, who strongly believe in the prosperity and globally competitive advantages 'standard English' has brought about to Singapore (Kramer-Dahl, 2003; Rubdy, 2007; Wee, 2011). According to Rubdy (2007, p. 308), "educators, parents and the lay public often echo similar views in the media, namely, that Singlish is a problem, a handicap, a blot", and hence constructing Singlish "as a less prestigious dialect associated with low social status." Singlish and the Singlish debate in Singapore concern both the government and individual Singaporeans, matters that question the nation's identity and are presented as a national issue (Wee, 2011).

Japan and Korea are among the countries that have been investing the most heavily in English language education to bring the overall proficiencies among their citizens to a more competitive level in the Asian region (Nunan, 2003; Sungwon, 2007; Seargeant, 2008; Rivers, 2011). There have even been initiatives to turn Korea from an Expanding Circle country to an Outer Circle country, shifting the status of English from a foreign language to a second language. Neither of these countries were former colonies of any English-speaking Western countries, but they are both closely connected to the USA through military dependence. This dependence has extended to all other aspects of their societies, among which their pro-English policies are believed to deepen their dependence and enhance their inner capacities and international status at the same time. Following other countries in the region, Vietnam is emerging as a major player in promoting English across its educational system. English is still a foreign language in Vietnam but is on the fast rise with the government's ambitious language policy to make English compulsory from Grade 3 by 2020. To realise this policy, the government has approved the National Foreign Language Project 2020, mobilizing \$US2 billion from both governmental and non-governmental sources to promote English language education at all levels (Nguyen, 2011).

Many Asian countries have responded to the global role of English in ways that are specific to their identities, histories, local politics, economic development and nation building strategies and specific to what role English plays in relation to a dominant national language. Former colonies of Britain, such as India, Singapore and Malaysia, in different ways promote English as a shared historical heritage for their national cultural identity formation and for their national, cultural, racial, linguistic and ethnic reconciliation. Other Asian countries including Japan and Korea navigate their foreign language policies towards an almost absolute preference for English to achieve their nation building missions that are also shaped by the globalization of English (Hashimoto, 2007; Rivers, 2011; Seargeant, 2008; Phan Le Ha, 2013). But all in all, the promotion of English does come with problems associated with ethnic relations, access to education, social equity, and cultural identity issues, as we later demonstrate with the case of Malaysia.

\section{A Brief History of the Malaysian Education System}

The formal education system in Malaysia began during the period of British colonial rule, when the colonial objectives of exploiting Malaya's rich resources and developing a docile body of native supporters penetrated through the education system in terms of both structure and practice (Malakolunthu and Rengasamy, 2012). In the $19^{\text {th }}$ century, the British introduced labourers from China and India to work in various economic sectors for them, and their practice had resulted in the unequal distributions of Malay, Chinese and Indian communities across the rural and urban areas of Malaya. Most Malays and Indians were left to work in the fields and plantation estates respectively, whereas the Chinese were involved in the mining industry but had also a strong presence in urban 
areas as entrepreneurs (Hashim, 2009). By the time of independence, the population of Malaya was mainly comprised of Malays as the dominant ethnic group (50\%), Chinese (38\%), Indians (11\%) and other minor indigenous groups (Malakolunthu \& Rengasamy, 2012, p. 147).

Since the British had an agreement with the Malay rulers as to not interfere with the Malay customs and the Islamic religion that dominated throughout rural areas, most of the English-medium schools were established and supported by the British in urban areas (Watson, 1980). The purpose of these English-medium schools was to create a local workforce to undertake the support-staff positions for their administrations (Malakolunthu and Rengasamy, 2012). Primary and secondary level education were made available in these English-medium schools; and they were established in the urban areas and were mainly attended by elite Malays as well as wealthier Chinese and Indians (Ozóg, 1993). Those who attended English-medium schools and became English-knowing bilinguals had better social mobility as they were able to pursue tertiary studies and become professionals (Ozóg, 1993).

The Malay community did not have a formal education system until the late 19th century when the British helped establish vernacular schools for the Malays. These schools only provided primary education with English deliberately excluded from the curriculum since the British had no interest in creating opportunities for them to progress beyond their villages besides training them into being better cultivators and good citizens (Ozóg, 1993; Powell, 2002). Meanwhile, the Chinese and Indian communities established and funded their own vernacular schools with curriculums imported from their respective homelands as they were unregulated by the British (Powell, 2002). Malay and Tamil medium schools, which only offered primary education, were mainly found in rural Malaya whereas the Chinese-medium schools that offered up to secondary education were mostly located in urban centres (Watson, 1980).

As a result, British colonisation created a diverse education system of mainstream and vernacular schools i.e. English, Malay, Chinese and Tamil. This also served to maintain the social and economic segregation among the ethnic groups by limiting the possibility for social mobility and by providing different forms of education to different ethnic groups (Watson, 1980; Powell 2002). Eventually, the British saw that ethnic tensions were rising and realised that the economic, social and political progress in Malaya could be slowed down if these tensions were not solved (Ozóg, 1993).

They recognised that educational and language policies that focus on unity could be a solution (Ozóg, 1993), and hence the drafting of the Barnes and the Fenn-Wu reports in 1951 that outlined various proposals regarding the choice of language used as the MOI (Hashim, 2009). A compromise was eventually reached in the 1956 Razak Report, which proposed the establishment of two types of primary schools: the 'national school' that would use Malay as the MOI, and the 'national-type' school which could use either English, Chinese or Tamil as the MOI (Hashim, 2009). The Razak Report, which became the 1957 Education Ordinance, also recommended that schools at the secondary level had to be national schools, although Chinese secondary schools could still continue using Chinese as the MOI provided that they adopted common syllabi and examinations (Hashim, 2009, Puteh, 2010).

In the first few decades after Malaya gained independence from Britain in 1957, there were several changes in the language policy that were implemented for nationalistic and economic reasons, and which not only impacted the educational system but also the socio-economic environment throughout the nation. On the one hand, language policy was used by the state to achieve national unity for the post-colonial nation through promoting the use of a national language (i.e. Malay) within the educational system. On the other hand, the various changes in the language policy eventually created unforeseen problems that people perceived were disadvantaging the population in an increasingly globalising world, leading to a need to redress the language policy through language planning that promoted the use of English again. However, new issues arose when the new language policy was seen to undermine the privileged status of the national language (Chan and Tan, 2006). The state encountered a dilemma of whether to continue enforcing the use of the national language to maintain national identity or to encourage people to be more proficient in English in order to compete in the globalised world. Consequently, the language policy became a site of contestation 
between the use of Bahasa Malaysia and English as the MOI. Specifically, in the past 10 years, Malaysia has introduced two major policies regarding the MOI. The first one involves the sudden change from Bahasa Malaysia to English for Mathematics and Science in 2003, which was reversed in 2012. This reversal has resulted in the introduction of a new language policy, that is, 'To Uphold Bahasa Malaysia \& To Strengthen the English Language' (MBMMBI). In this article, we will focus on these two policies in particular.

\section{Nationalism, the Nation State, and Use of Language to Claim, Exert, Maintain and Resist Power}

Anderson (1991, p. 6) defines the nation as "an imagined political community" because every member of the nation is able to visualise the communion with other members despite having never met, heard or even known each other. Anderson states that the origins of national consciousness came about with the rise of print-capitalism, which led to a new form of imagined national consciousness that later set the stage for the modern nation. Print-capitalism enabled "a system of communication with [people] outside their narrow circle of social relations" through using a common language, as well as raising awareness of the millions of people in their respective language-field (Safran, 2010, p.56). Hence, Anderson (1991, p. 134) emphasizes the importance of print when he asserts that "print-language is what invents nationalism, not a particular language per se." That said, the elevation of a single language as the common medium of expression in print does likely facilitate the process of imagining a national community and this is why governments of newly developing nations have focused so heavily on the promotion of a national language.

Fishman (1968) has examined the significant role that a national language can play in fostering a sense of national unity among members of newly developing nations. Newly formed nations encounter problems as their political boundaries do not always correspond to a unified ethnic-cultural entity. Without a common national identity, these new nations "proceed to plan and create such an identity through national symbols that can lead to common mobilisation and involvement above, beyond, and at the expense of pre-existing ethnic-cultural particularities" (Fishman, 1968, p. 6). Such national symbols include choosing a local language and elevating it as the national language, which is frequently invoked as a unifying symbol through which speakers of the language identify themselves as members of the nation; and nationalists view language as representing "the continuity of a Great Tradition with all of its symbolic elaborations in terms of ideologised values and goals" (Fishman, 1968, p. 9). Therefore, a national language does not only work as a symbol to raise a sense of national unity, but it also reinforces and maintains a sense of cultural value and identity. As the nation elevates and reinforces the language of the ethnic Malays as the national language of Malaysia, that national language then serves to legitimise that group's (i.e., the Malays') status and to facilitate its political dominance over other ethnic groups.

No power, however, is absolute, and we see this in the way that national languages are resisted at the same time that they are promoted. Kubota's (2004, p. 22) argument that "language is used to produce particular knowledge that fulfils certain political and ideological purposes and to exert, maintain, or resist power" is evident in the Malaysian context where language has been used in policies to achieve particular ideologies, and to resist certain ideologies. Examples include the use of Bahasa Malaysia as the national and official language by the Malays - the dominant ethnic group - in the early days of independence to claim, legitimise and exert political power. They also include the continued use of English by the non-Malays in the business domain, particularly the Chinese, as a means to resist power as an ethnic minority (Gill, 2005, 2006, 2007; Hashim, 2009; Puteh, 2010; Seah, 2000; Liu and Ricks, 2012).

\section{Bahasa Malaysia as a National Language for Malays to Claim and Exert Power}

During the time when the Education policy was shaped, the Barnes Report of 1951 proposed a single inter-ethnic type of national school which aimed to create educational unification based 
on Malay-English bilingualism, hence transforming all vernacular schools into this type of national school (Puteh, 2010). However, the proposals of the Barnes Report were superseded by the more influential Razak Report of 1956 which became the Education Ordinance of 1957 that supported the development of mother tongue education and vernacular schools (Gill, 2005).

The decision to allow for vernacular language education over the bilingualism proposed by the Barnes Report was influenced by the British policy of preparing Malaysia for self-rule being conditional on an agreed sharing of power among the ethnic communities (Mead, 1988). Political parties based on ethnic lines developed, with the United Malays National Organisation (UMNO) representing the Malays, the Malaysian Chinese Association (MCA) representing the Chinese and the Malaysian Indian Congress (MIC) representing the Indians. The Malays wanted to legitimise their status as 'sons of the soil' (bumiputeras) in relation to the Chinese and Indians who came as migrants (Gill, 2005, p. 245) and a 'bargain' was struck between these groups where Malay political dominance was informally exchanged for immigrant citizenship (Muhamat @ Kawangit et al., 2012).

This 'bargain' brought about a precarious coalition of parties without a common language, religion, ethnicity or culture, while upholding Malay supremacy. In 1957, Malay-medium schools were endorsed as the national schools and vernacular schools as national-type schools (Malakolunthu and Rengasamy, 2012). This system was allowed only for primary education while education at the secondary and higher levels could only be taught in Bahasa Malaysia. For the Malays, this language policy served as an instrument for nation-building and as a tool to create a national identity (Liu and Ricks, 2012), but allowing for vernacular schools to exist represented compliance with the conditions of the British for independence.

Not long after this system was put it place, it was changed in response to ethnic riots that broke out in 1969. These riots were between the Chinese and Malays and raised concerns about the state of national unity in the country. As a remedy, the government introduced a charter of national principles called 'Rukun Negara', or "National Principles', which became the guiding principles for all future policy making (Malakolunthu and Rengasamy, 2012). At the same time, a policy known as the New Economic Policy (NEP) was implemented in 1970 to assist the Malays to overcome their economic backwardness in relation to the non-Malays (Mead, 1988). This policy brought many direct benefits to the Malays in the educational realm, preference for placement into universities, the establishment of the MARA Institute of Technology which was reserved only for the Malays, the expansion of school facilities to rural areas and the granting of government scholarships for further education overseas (Malakolunthu and Rengasamy, 2012). Finally, as a result of the riots, by 1983 Bahasa Malaysia became the main MOI throughout the educational system, including in public universities (ibid, p. 152).

\section{The Use of English by Chinese to Claim One Power and Resist Another}

The changes delivered by the NEP deepened the natural divides in a multi-ethnic society (Malakolunthu and Rengasamy, 2012, p.147). The legitimisation of Malay supremacy through the NEP has permeated Malaysian society at all levels and has left the non-Malays feeling marginalised (ibid, p. 152). The Chinese resist Malay supremacy through maintaining the use of Chinese at national-type schools and English in the business domain where there is no legislation preventing its use (Gill, 2005). The efforts of the Chinese community to retain their ethnic identity through vernacular schools has been aptly described as coming about "only through blood, sweat, tears and the sheer political will of the Chinese community in this country to defend their mother-tongue education. . . truly, a protean saga" (Kua, 1992 cited in Gill, 2007, p.114). This has been described by Canagarajah (1999) who posits that the exercise of power always implies the existence of counterpower or counter discourses, as "power is sustained at the micro-level by diverse local networks encompassing personal and collective domains, that is, in relationships, in social institutions, and in community life. But this interlocking system of power provides scope for tension and conflict between the divergent domains to enable opposition and change" (p. 33). 
While English may have officially been relegated to second place through education policy in Malaysia, the Chinese communities' continued use of the language has helped maintain its importance in the private sector. As a result of the preferential placement given to Malays at public universities, many Chinese have had to continue their education at overseas universities where English is the MOI. As such, many educated non-Malay Malaysians of the older generation who enjoyed bilingual $\mathrm{MOI}$ under the British colonial administration continue to expect their children to excel at the English language. In contrast, despite consistent support from the government in all domains of education, the Malays have been more reluctant learners of English (Karchner-Ober, Mukherjee, and David, 2011). The Chinese have been able to resist the dominant group not only through learning the Malay language but also by retaining the use of English, which arguably has the highest linguistic value in the world, in the business domain (Gill, 2006).

\section{Policy Changes due to Industrialisation and Globalisation: The Change from Bahasa Malaysia to English as the MOI for Mathematics and Science (PPSMI)}

In the 1980s, Malaysia attracted many direct foreign investments through multinational companies and this led to a need for a supply of skilled workers (Malakolunthu and Rengasamy, 2012). Further, these foreign companies relied heavily on English as the medium of communication (Puteh, 2010). As a response to this phenomenon, the government introduced the Education Act 1996 which allows for the use of English as the MOI for technical areas in post secondary courses; and the Private Higher Education Institute Act which allows the use of English in courses provided through twinning with foreign universities (ibid.).

This new education philosophy incorporated the government's new National Vision 2020 ideals which aim for Malaysia to become an industrialised nation by the year 2020, warranting a change in the education policy to prepare the nation in order to produce and provide the right mix of human capital (Malakolunthu and Rengasamy, 2012). However, the Higher Education policy led to a bifurcation in the tertiary sector where public universities conduct their courses through Bahasa Malayasia as the $\mathrm{MOI}$ while the private universities conduct their courses through English as the $\mathrm{MOI}$. As a result, graduates from private universities, because of their fluency in English and the marketability of their courses, were in greater demand in the private sector than graduates from public universities (Gill, 2007). From 1960 to 1990, the civil service was the largest employer of graduates from public universities (Gill, 2005), with over one million employed, making Malaysia the largest employer of a civil workforce in Asia (Gill, 2007). When the government pulled back on its employment of public university graduates, some 40,000 were unemployed in 2002 (Mustapha, 2002 cited in Gill, 2005) and this was largely seen as being a Malay problem as most of the public university graduates were Malays.

The non-bumiputeras (Indians and Chinese) continued to be ahead of the Malays on most economic, social and educational indexes (Khoo, 1995 cited in Gupta, 2010) and on average, achieved higher results than bumiputeras in the Malay-based education system (Schiffman, 1996 cited in Gupta, 2010). The government felt that changes must be made to the policy to ensure that the bumiputeras would not continue to be left behind with a weak competency in English as that would lead to serious problems of unemployment in the private sector for graduates from public universities (Gill, 2006); and this was the impetus behind the change in 2002 from Bahasa Malaysia as the $\mathrm{MOI}$ in Mathematics and Science to English as the MOI, termed PPSMI.

Gill $(2006$, p. 88) noted that the government would not have instituted such a change if it had not been necessary for the progress and development of the Malays. In Malaysia, language policy and planning processes are often 'top-down' processes where people of power and authority make decisions with little or no consultation with the ultimate language learners and users (Kaplan \& Baldauf cited in Gill, 2006; Dumanig, David and Symaco, 2012) and must usually be discussed in the context of politics (Karchner-Ober, Mukherjee, and David, 2011). This policy change, however, was even less consultatitve in that it was simply announced through the media by the then Prime Minister 
(PM) Dr. Mahathir (Gill, 2007). Gill (2006, p.89), from an interview with the PM, postulated that the possible reason for not wanting to provide the opportunity for consultation and discussion emerged out of the strong resistance posed by Malay intellectuals at public universities to the first attempt at change in the $\mathrm{MOI}$ to English for science and technology more than ten years earlier in 1993.

After all, the Malay intellectuals are a strong and cohesive group with social and political clout (Gill, 2006). According to Hall (1997), representation through language is closely tied up with identity and knowledge and when related back to the Malaysian context, a language change would represent a threat to the Malays' identity as the superior ethnic group. When the MOI is Bahasa Malaysia, their bumiputera status is legitimised and this could give them both symbolic and concrete power to influence decision-making on language issues and the nation (Gill, 2005, p.245); but if the $\mathrm{MOI}$ is changed to English, which is perceived to be a neutral language to all the ethnic groups in Malaysia, this aspect of their Malay identity may be threatened. Furthermore, this change would further disadvantage the Malays with their lack of competency to access information and to communicate in English as compared to non-Malays (Gill, 2005). However, to the Malay leadership, modernisation is just as important as nationalism.

The Malaysian bureaucracy and its social institutions are decidedly one of the most modern of post-colonial societies moulded arguably from considerable western influences. Successive Malaysian leaders had striven hard to project themselves as progressive and innovative as any leader of the modern era while maintaining their own distinct cultural identity and embracing traditional values. (Shome, 2002, p.1)

These divergent views within the dominant group calcified into a 'coup' through which the PM changed the MOI to English without consent from the Malay intellectuals.

The way in which PPSMI was announced caused problems that compromised its viability and implementability. Firstly, many academics did not regard PPSMI as a change in policy as it was not legislated for and the National Education policy still stated that "the national language is the main medium of instruction for the national education system" (Gill, 2006, p. 83). There were no directives from the Ministry of Education that stipulated guidelines for the implementation of this policy, hence, in 2005, when the first cohort of PPSMI students entered university, they were disappointed to find that only 30 percent of their courses were conducted in English and the rest were still taught in Bahasa Malaysia (Gill, 2006, p. 91). Secondly, teachers were not qualified to conduct content-based learning in English (Tan, 2011) especially after 30 years of cultivating Bahasa Malaysia as the $\mathrm{MOI}$ and this was exarcebated by the short time of six months from the time of the announcement of the policy in June 2002 to its implementation in January 2003. Tan's study (2011) found that the buddy system in place at schools between English language teachers and Mathematics and Science teachers were insufficient to compensate for the lack of skills for language teachers to teach content-based materials.

Resistance also came from the Chinese. The Malaysian-Chinese Schools, backed by the United Chinese School Committees' Association of Malaysia (Dong Jiao Zong) is a very powerful organisation which ferociously guards the rights of Chinese to retain their language (Karchner-Ober, Mukherjee, and David, 2011). Before PPSMI, national schools used Bahasa Malaysia as the MOI for all subjects except for English while national-type schools used Tamil or Chinese as the MOI for all subjects except for English and Bahasa Malaysia (Asmah, 1987 cited in Gill, 2007). With PPSMI, however, the national-type schools and the national schools were to become similar in that they were both supposed to teach Mathematics and Science in English. However, since students in Chinese MOI schools had long outperformed their counterparts in the national schools, they did not feel the need to change to English, hence, a negotiation ensued and it resulted in a compromise where Mathematics and Science were taught in both English and Chinese in the Chinese schools (Gill, 2007). At the same time, Lim and Presmeg's (2010) study found that the learning culture in the Chinese schools did not promote the usage of English, hence it did not facilitate their learning in English and this had serious repercussions on the academic futures of students from Chinese schools in 
the Malaysian educational system which measures academic achievements through standardised, high stakes, public examinations.

The switch from Bahasa Malaysia to English as the MOI for Mathematics and Science was justified by Dr. Mahathir's reconceptualisation of nationalism from a "linguistic nationalism. . . [to] knowledge-driven nationalism and development-orientated nationalism" (Gill, 2006, p. 84), which provided a space for the national identity to be renegotiated, particularly within the Malay community. In light of this reconceptualization of nationalism, we can argue that the Malaysian cultural identity had the opportunity to strategically reposition itself through the construction of English as a tool for national development rather than as the ex-coloniser's language, as learning English was considered as an act of patriotism. This reconceptualisation of nationalism, as such, showed that there are other possible ways for Malaysians to be patriotic (i.e. nationalist) without destabilising the national identity.

However, Dr. Mahathir's approach in implementing the change of the $\mathrm{MOI}$ without consultation with the Ministry of Education resulted in poor structural implementation as the educational system was unprepared to adapt to the sudden change. Studies have found that the teaching of Science and Mathematics in English was problematic and did not improve students' proficiency in English as desired (Hashim, 2009). Specifically, according to the Ministry of Education Malaysia (2010), many schools continued to deliver both subjects in the Malay language. As for the schools that did attempt to teach in English, when students experienced difficulty learning both subject matters in English, teachers were forced to teach in Bahasa Malaysia to help students understand the subject matter better. This problem was prevalent especially in rural areas, and a widening gap in academic performance for both subjects emerged between the rural and urban areas during the period of the implementation of this policy (Ministry of Education Malaysia, 2010).

\section{'To Uphold Bahasa Malaysia \& To Strengthen the English Language' (MBMMBI): The Way Forward}

The unsuccessful implementation of English as the MOI for Mathematics and Science for schools eventually pressured the Malaysian Government to reverse its actions by introducing a new language policy in 2010, that is, 'To Uphold Bahasa Malaysia \& To Strengthen the English Language' (MBMMBI). The MBMMBI aims to uphold the rightful position of Bahasa Malaysia not only as the national language but also as "the main language of communication, language of knowledge, and the language for nation-building crucial towards achieving the objectives of 1Malaysia" (Ministry of Education Malaysia, 2010, p. 6). Furthermore, the MBMMBI strives to strengthen proficiency in the English language as the international language of communication and knowledge, hence enabling the exploration of knowledge that is vital for one to compete nationally and globally.

The ideological repositioning of Bahasa Malaysia and English beyond their respective roles as national and international languages of communication not only suggests that Bahasa Malaysia has been taken for granted as part of a national identity for nation-building, but that it also has the potential to produce its own body of knowledge at the same time that English is relied on to empower the nation's citizens to compete in today's era of globalisation. Furthermore, the process of privileging the status of Bahasa Malaysia beyond being a marker of the Malay(sian) identity involves complex negotiations for what it means to be a Malaysian today. On the one hand, being nationalistic means to uphold the explicit markers that define the nation's identity (i.e., the Malay language). On the other hand, being nationalistic also means acknowledging the importance of strategically harnessing the benefits of the antithesis of those markers that work to the advantage of the nation on the global stage (i.e., the English language).

However, a nation's language policy is nowadays often driven by national as well as regional and global factors, among which the nation building project, the increasing international role of English and the intensification of globalisation tend to be the most heavy-weight (Tsui and Toleffson, 2007; Phan Le Ha, 2013). In particular, the process of globalisation has involved many individuals in networks 
that "negate political and linguistic boundaries" (Wright, 2012, p. 75). The advent of globalisation also democratises the flow of knowledge, especially through the World Wide Web, which means that for many people, "the imagined community to which they belong is no longer exclusively the nation" (Wright, 2012, p. 76); and as such, knowledge of the national language is no longer sufficient as "people need a linguistic repertoire which allows them to cross linguistic boundaries" (ibid, p. 76).

In this regard, we argue that English should be given a more stable and strategic status alongside Malay as the national language to formally recognise the role of English in aiding the development of the nation, as argued by many scholars, including Hashim (2009), Dumanig, David, and Symaco (2012) and Ali (2013). This recognition also echoes Former Prime Minister Mahathir Mohammed's strategic view on nationalism/patriotism discussed earlier (i.e. knowledge-driven nationalism and development-orientated nationalism), in which the mastery of English could serve the nation in many fruitful ways. Rather than having a fixed view on English as the ex-coloniser's language, Malaysia as one nation can strategically reposition itself through embracing English for national development. There are indeed other possible ways for one to be patriotic (nationalist), and learning English would be considered as an act of patriotism. This is what has already taken place in Singapore, as documented by Silver (2005), Rappy and Wee (2006) and Chew (2007) to name a few.

Furthermore, English could also be positioned as a language of strategic neutrality whereby the status of English as a lingua franca for Malaysians to communicate with the global community is promoted (Wee, 2010). By acknowledging the strategic neutrality position of English, English might then not be perceived as a threat to Malay, the national language. Nevertheless, it is important to note that other ethnic languages, such as Mandarin and Tamil, may one day fight for their rights to be recognised as official languages. As reminded by Hashim (2009, p. 49), "it should not be forgotten that language planning and education policy should not rest entirely on economic considerations but on the recognition of and respect for linguistically expressed cultural identities". This is also what Phan Le Ha (2013) has argued in her analysis of Japan's language and education policy.

To further our line of thoughts, if the implementation of Malay as the MOI has successfully established national unity and a common identity whereby "Malaysians of all ethnic groups are generally able to interact in Malay and use Malay in communication between different ethnic groups," as discussed by Hashim (2009, p. 45), then on the basis of this shared identity, a strategic balanced plan to promote the use of English as an $\mathrm{MOI}$ in certain key areas at the university level would benefit Malaysia's self-projection as a hub of international education and knowledge (Ministry of Higher Education, 2010). This can also be another identity for the nation, which does not have to contradict or disadvantage the Malay community either.

It is still too early to say if this new policy will be a success, and we acknowledge that there are multiple ways in which one can read the policy. Nevertheless, taking into consideration many issues concerning the over-reliance on English in education and language policies throughout Asia (Rappy and Wee, 2006; Tsui and Toleffson, 2007; Phan Le Ha, 2013) and the many advantages of multilingualism (Philippson, 2009, 2010, 2012), the MBMMBI policy change can be seen as a positive move that might ensure the preservation and progress of Bahasa Malaysia alongside the English language. Hypothetically, while the promotion of Bahasa Malaysia as MOI may not be viewed favourably by non-Malay ethnic groups in Malaysia in the first place, this at least responds to the social, economic, intellectual, cultural and linguistic needs of the Malays who are still the majority in the nation, most of whom would benefit much more from having their native language as $\mathrm{MOI}$ while enjoying more access to English.

We also argue that this MBMMBI policy could enable the government to further develop bilingual capabilities, at least within the Malay population, at a scholarly level that could enable the creation of a body of knowledge that concurrently engages in intellectual exchange within Malaysia through Bahasa Malaysia and with the international community through English.

As stated in the Malaysian Education Blueprint, the language policy aims for attainment of bilingual education which will continue to uphold Bahasa Malaysia and seek for improvement in English (Ministry of Education Malaysia, 2012). English has already earned its place within Malaysia 
as the language of commerce and of higher education in the private sector and will continue to be regarded as a language laden with desirable capital, given what has been discussed in this article so far. If the status of Bahasa Malaysia is not supported through language policy in education, it may be at risk of being usurped by English through globalisation of all kinds. The motivations of learning English as a second language can be seen as being synonymous with the understanding that people will acquire a symbolic resource that has a good return on investment in the global knowledge economy.

The advent of globalisation has contributed to making English a necessity for international communication, and this has highlighted the need for nation-states to preserve national identity to distinguish themselves against each other, as recently noted by scholars working in Malaysia, including Dumanig, David, and Symaco (2012). While the mastery of English enables Malaysia to achieve a cosmopolitan identity (Dumanig, David, \& Symaco, 2012) and much more, the act of upholding and elevating the status of Bahasa Malaysia beyond its role as the national language could be regarded as a strategic move to redirect the purpose and importance of using Bahasa Malaysia. Despite the high cultural capital of English, Bahasa Malaysia will always remain relevant to the Malaysian society if it manages to successfully establish itself as the "the main language of communication, language of knowledge, and the language for nation-building" (Ministry of Education, 2010).

However, we also want to emphasise that oscillating between English as the $\mathrm{MOI}$ and Bahasa Malaysia as the MOI has so far contributed to ambiguities in language choice for teaching at public universities in Malaysia, and Ali (2013) argues that this will likely continue to impact the ability of universities to plan their curricula to equip the younger generation with proficiency in English so that they can participate in the global economy. Policy directives towards achieving bilingualism in education run the risk of failing if not well conceived and implemented. Therefore, when this new policy rightly positions Bahasa Malaysia as a legitimate language of advanced intellectual exchange and knowledge production, it has the potential to balance the over-reliance on English for scholarly and academic knowledge generation, if well received and realised by all parties involved. This very issue has been well discussed in Phan Le Ha (2013) in which she documents Japan's English language and higher education policies and their impacts on the internationalisation of intellectual engagement and knowledge production when the over-reliance on English has become the norm in numerous government policies these days.

To conclude, although we support Hashim's (2009, p. 45) argument that "bilingualism and multilingualism must be promoted for national identity, for instrumental use, for ethnic and personal identity, and the importance of culture and values", we contend that Malaysia is not ready for bilingualism and multilingualism throughout its entire educational system yet. Therefore, the implementation of 'To Uphold Bahasa Malaysia \& To Strengthen the English Language' (MBMMBI) is important, necessary and timely, as it will enable Malaysia to take gradual steps to achieve its aims and to respond strategically to the many problems associated with the over-reliance on English and the over-promotion of this language, as discussed earlier. This policy is also a necessary, firm, strategic and timely response by the Malaysian government to globalisation, nation building, the increasing international role of English, and the pressure to maintain national cultural identity in today's world.

\section{References}

Ali, N. L. (2013). A changing paradigm in language planning: English-medium instruction policy at the tertiary level in Malaysia. Current Issues in Language Planning, 14(1), 73-92.

Altbach, P. \& Knight, J. (2007). The internationalisation of higher education: motivations and realities. Journal of Studies in International Education, 11, 3/4, 290-305.

Anderson, B. R. O. G. (1991). Imagined communities: Reflections on the origin and spread of nationalism. London: Verso.

Canagarajah, S.A. (1999). Adopting a critical perspective on pedagogy. In A. S. Canagarajah, Resisting Linguistic Imperialism in English Teaching. Oxford: Oxford University Press, pp. 9-37. 
Chan, S. H. \& Tan, H. (2006). English for mathematics and science: Current Malaysian language-ineducation policies and practices. Language and Education, 20(4), 306-321.

Chew, P. (2007). Remaking Singapore: language, culture and identity in a globalised world. In Tsui, A. \& Tollefson, J.(Eds.) Language policy, culture, and identity in Asian contexts. Mahwah, New Jersey: Lawrence Erlbaum Associates Publishers, 73-94.

Crystal, D. (2003). English as a global language. Oxford: Oxford University Press.

Dumanig, F. P., David, M. K., \& Symaco, L.P. (2012). Competing roles of the national language and English in Malaysia and the Philippines: Planning, policy and use. Journal of International and Comparative Education, 1(2), 104-115.

Fishman, J. A. (1968). Sociolinguistics and the language problems of the developing countries. In J. A. Fishman, C. A. Ferguson \& J. D. Gupta (Eds.), Language problems of developing nations. New York: John Wiley \& Sons, Inc., pp. 3-16.

Gill, S. K. (2005). Language policy in Malaysia: Reversing direction. Language Policy, 4, 241-260.

Gill, S. K. (2006). Change in language policy in Malaysia: The reality of implementation in public universities. Current Issues in Language Planning, 7(1), 82-94. [doi: 10.2167/cilp083.0].

Gill, S. K. (2007). Shift in language policy in Malaysia. AlLA Review, 20, 106-122.

Gupta, A. F. (2010). When mother-tongue education is not preferred. Journal of Multilingual and Multicultural Development, 18(6), 496-506.

Hall, S. (1997). Introduction. In S. Hall (Ed.), Representation: Cultural representations and signifying practices. London: Sage Publications/Open University Press, pp. 1-12.

Hamid, A. \& Moni, K. (2011). English in primary education in Malaysia: Policies, outcomes and stakeholders' lived experiences. Current Issues in Language Planning, 12(2), 147-166.

Hashim, A. (2009). Not plain sailing: Malaysia's language choice in policy and education. AlLA Review, 22(1), 36-51. [doi: 10.1075/aila.22.04has]

Hashimoto, K. (2007). Japan's language policy and the "lost decade". In Tsui \& Tollefson (Eds.), Language policy, culture, and identity in Asian context. Mahwah, NJ: Lawrence Erlbaum Associates, pp. 26- 36.

Huang, F. (2009). The internationalization of the academic profession in Japan: A quantitative perspective. Journal of Studies in International Education, 13(2), 143-158.

Jenkins, J. (2009). English as a Lingua Franca: interpretations and attitudes. World Englishes, 28(2), 200-207.

Kachru, B.B. (1986). The alchemy of English: The spread, functions, and models of non-native Englishes. Oxford: Pergamon

Kachru, B. B. (1985) Standards, codification and sociolinguistic realism: the English language in the outer circle. In R. Quirk \& H.G. Widdowson (Eds), English in the World: Teaching and Learning the Language and Literatures. Cambridge: Cambridge University Press, pp. 11-30.

Karchner-Ober, R., Mukherjee, D., \& David, M. K. (2011). Multilinguality in the Malaysian context of nation-building and globalisation. In D. Mukherjee, \& M. K. David (Eds.), National Language Planning and Language Shifts in Malaysian Minority Communities: Speaking in many tongues. Amsterdam: Amsterdam University Press, pp. 173-184.

Kirkpatrick, A. (2012). (Ed.). English as an International Language in Asia: Implications for Language Education. Netherland: Springer.

Kramer-Dahl, A. (2003) Reading the "Singlish Debate": Construction of a Crisis of Language Standards and Language Teaching in Singapore, Journal of Language, Identity \& Education, 2(3), 159-190.

Kubota, R. (2004). The politics of cultural difference in second language education. Critical Inquiry in Language Studies, 1(1), 21-39.

Lim, C. S., \& Presmeg, N. (2011). Teaching mathematics in two languages: A teaching dilemma of Malaysian Chinese primary schools. International Journal of Science and Mathematics Education, 9(1), 137-161.

Liu, A. H., \& Ricks, J. I. (2012). Coalitions and language politics: Policy shifts in Southeast Asia. World Politics, 64(3), 476-506. 
Malakolunthu, S., \& Rengasamy, N. (2012). Education policies and practices to address cultural diversity in Malaysia: Issues and challenges. Prospects, 42(2), 147-159. [doi: 10.1007/s11125012-9227-9].

Mead, R. (1988). Malaysia's national language policy and the legal system. New Haven: Yale University Southeast Asian Studies.

Ministry of Education Malaysia. (2010). To uphold Bahasa Malaysia \& to strengthen the English language. Available at http://www.moe.gov.my/mbmmbi/moe_mbmmbi_03.htm. [Accessed on 11 June 2013].

Ministry of Education Malaysia. (2012). Preliminary Report Malaysia Education Blueprint 20132025. Available at http://www.moe.gov.my/userfiles/file/PPP/Preliminary-Blueprint-Eng.pdf. [Accessed on 11 June 2013].

Muhamet @ Kawangit, R., Don, A. G., H, Hamjah, S. H., Sham, F. M., Nasir, B. M., Asha'ari M.F., Siti, R.T., Zainab, I. ; Ideris, E. ; Anuar, P ., Ismail, A. and Ghani, M. (2012). The history of ethnic relationship in Malaysia. Advances in Natural and Applied Sciences, 6(4), 504-510.

Mukherjee, D., \& David, M. K. (2011). Introduction: Language policies at variance with language use in multilingual Malaysia. In D. Mukherjee \& M. K. David (Eds.), National language planning and language shifts in Malaysian minority communities: Speaking in many tongues. Amsterdam: Amsterdam University Press, pp. 13-22.

Nguyen, N.H. (2011). An overview of Vietnam's national foreign language project. Paper presented at The $3^{\text {rd }}$ Engaging with Vietnam Conference, Hanoi Vietnam, 4-5 December.

Nunan, D. (2003). The impact of English as a global language on educational policies and practices in the Asia-Pacific region. TESOL Quarterly, 37(4), 589-613.

Ozóg, A. C. K. (1993). Bilingualism and national development in Malaysia. Journal of Multilingual and Multicultural Development, 14(1-2), 59-72. [doi: 10.1080/01434632.1993.9994520]

Phan Le Ha (2013). Issues surrounding English, the internationalisation of higher education and national cultural identity in Asia: A focus on Japan. Critical Studies in Education, 54(2), 160-175.

Phillipson, R. (2009). The tension between linguistic diversity and dominant English. In SkutnabbKangas, Tove, Ajit Mohanty, Minati Panda and Robert Phillipson (eds.). Social justice through multilingual education. Bristol: Multilingual Matters, 85-102.

Phillipson, R. (2010). Epilogue: querying language in 'English-medium' education. Language and Education, 24(1), 75-79.

Phillipson, R. (2012). One area, one market, one language: linguistic McDonaldisation and EU rhetoric. In Sprache(n) als europäisches Kulturgut. Languages as European cultural asset. Claudia Schmidt Hahn (Hrsg.) Innsbruck: Studienverlag, 115-126.

Powell, R. (2002). Language planning and the British Empire: Comparing Pakistan, Malaysia and Kenya. Current Issues in Language Planning, 3(3), 205-279. [doi: 10.1080/14664200208668041].

Puteh, A. (2010). The language medium policy in Malaysia: A plural society model? Review of European Studies, 2(2), 192-200.

Rajadurai, J. (2005). Revisiting the concentric circles: Conceptual and sociolinguistic considerations. Asian EFL Journal, 7(4), 111-130.

Rappy, A., \& Wee, L. (2006). Language policy and modernity in Southeast Asia: Malaysia, the Philippines, Singapore and Thailand. New York, NY: Springer.

Rivers, D. (2011). Japanese national identification and English language learning processes. International Journal of Intercultural Relations, 35(1), 111-123.

Rubdy, R. (2007). Singlish in the School: An Impediment or a Resource?, Journal of Multilingual and Multicultural Development, 28:4, 308-324.

Safran, W. (2010). Political science and politics. In J. A. Fishman \& O. García (Eds.), Handbook of language and ethnic identity (2nd ed., Vol. 1). Oxford: Oxford University Press, pp. 49-69.

Sakhiyya, Z. (2011). Interrogating identity: the International Standard School in Indonesia. Pedagogy, Culture \& Society, 19(3), 345-365. 
Seah, D. (2000). Malaysia: Dilemmas of Integration. In M. O'Neil, \& D. Austin (Eds.), Democracy and Cultural Diversity. Oxford: Oxford University Press, pp. 189-197.

Seargeant, P. (2008). Ideologies of English in Japan: The perspective of policy and pedagogy. Language Policy, 7(2), 121-142.

Seidlhofer, B. (2003). A concept of international English and related issues: From 'real English' to 'realistic English'? Available at http://www.coe.int/t/dg4/linguistic/Source/SeidlhoferEN.pdf. [Accessed on 1 August 2004].

Shome, A. S. (2002). Malay Political Leadership. London: RoutledgeCurzon.

Silver, R. (2005). The Discourse of linguistic capital: language and economic policy planning in Singapore. Language Policy, 4(1), 47-66.

Singh, M. (2010). Ignorance, Bradley's international students and Bourdieu. Australian Journal of Education, 54(1), 31-45.

Singh, M. \& Han, J. (2008). The commoditization of English and the Bologna Process: Global products and services, exchange mechanisms and trans-national labour, in P. Tan \& R. Rubdy (Eds.), Language as Commodity: Global Structures, Local Marketplaces. London: Continuum, pp. 204-224.

Sungwon, Y. (2007). Globalisation and language policy in South Korea. In Tsui, A. \& Tollefson, J.(Eds.) Language policy, culture, and identity in Asian contexts. Mahwah, New Jersey: Lawrence Erlbaum Associates Publishers, 37-54.

Sugiharto, S. (2008). Saving local languages through printed materials. Available at http://www. thejakartapost.com/news/2008/02/29/saving-local-languages-through-printed-materials.html. [Accessed on 12 May, 2013].

Supriyanto. (2013). Kurikulum 2013, Pramuka Jadi Ekstrakurikuler Wajib. Available at http://www. suaramerdeka.com/v1/index.php/read/news_kedu/2013/05/16/157100/Kurikulum-2013Pramuka-Jadi-Ekstrakurikuler-Wajib. [Accessed on 18 May, 2013].

Tan, M. (2011). Mathematics and science teachers' beliefs and practices regarding the teaching of language in content learning. Language Teaching Research, 15(3), 325-342.

Tsui, A. \& Tollefson, J. (2007) (Eds.). Language policy, culture, and identity in Asian contexts. Mahwah, New Jersey: Lawrence Erlbaum Associates Publishers.

Watson, J. K. P. (1980). Cultural pluralism nation-building and educational policies in peninsular Malaysia. Journal of Multilingual and Multicultural Development, 1(2), 155-174. [doi: 10.108 0/01434632.1980.9994008].

Wee, L. (2010). 'Burdens' and 'handicaps' in Singapore's language policy: on the limits of language management. Language Policy, 9(2), 47-66.

Wee, $L$ (2011). Metadiscursive convergence in the Singlish debate. Language \& Communication $31,75-85$

Welch, A. (2011). Higher Education in South East Asia: changing balance, blurring borders. London: Routledge.

Wright, S. (2012). Language policy, the nation and nationalism. In B. Spolsky (Ed.), The Cambridge handbook of language policy. Cambridge: Cambridge University Press, pp. 59-78. 